\title{
Inclusive education in the opinion of the teachers from special pre-schools, regarding the chances of success of the inclusive actions towards particular groups of students, education participants, and teachers' seniority
}

\begin{abstract}
Iwona Chrzanowska, Inclusive education in the opinion of the teachers from special pre-schools, regarding the chances of success of the inclusive actions towards particular groups of students, education participants, and teachers' seniority. Interdisciplinary Contexts of Special Pedagogy, no. 25, Poznań 2019. Pp. 127-149. Adam Mickiewicz University Press. ISSN 2300-391X. DOI: https://doi.org/10.14746/ikps.2019.25.06

Within the context of the implementation of the inclusive education model, it seems important to learn the opinions of the teachers, particularly those teachers that are experienced in working with a child/student with a disability, regarding the chances of success of inclusive actions, both in the context of the type, and the level of severity of the developmental disorder, the hazard of the developmental disorder, as well as, regarding the remaining participants of inclusive education, i.e. students without or with special educational needs, however, displaying certain aptitudes. The text focuses on the teacher from the pre-school level of education, as well as, refers to the determination of their attitudes towards the realisation of the model of inclusive education, as related to their seniority.
\end{abstract}

KEY WORDS: Inclusive education, special educational needs, seniority of pre-school education teachers 


\section{Introduction}

Change seems to have been the most essential slogan dedicated to education in Poland, for quite some time. We are talking about the changes in the education system, however, including those related to the implementation of inclusive education as well. The necessity of introducing the idea of inclusive education is a direct effect of Poland's obligations, related, e.g. with adopting the Convention on the Rights of the Persons with Disabilities (Konwencja o prawach osób niepetnosprawnych), ratified in 20121. However, the issue with implementing changes is, that at least a part of them does not seem to be well planned, or discussed with its main recipients. Therefore, they cause concern and, at times, objections. Bogusław Śliwerski, while writing about educational policies, indicates the lack of the democratisation of Polish education, that has lasted in the process of centralisation and of monopolisation of solutions for years ${ }^{2}$.

Additionally, in the case of the title issue of the inclusive education, for the success of the actions in this area, it is essential, whether the conditions for the realisation of the idea were created on the system level.

Inclusive education, as a postulate of changes in the educational system, is the effect of a process which is still in motion, and focuses on the change of the approach towards disability, including the education of persons with disabilities, and with special educational needs. Additionally, the matter of special educational needs, the awareness that they may vary depending on the developmental and real-life situation of the child/student, has been present in the inquiries of theoreticians and practitioners, at least since the 1970s ${ }^{3}$. In

${ }^{1}$ Konwencja o prawach osób niepetnosprawnych, Dz.U. RP z 25 października 2012 r., poz. 1169, www.isap.sejm.gov.pl [access: 15 February 2019].

2 B. Śliwerski, Edukacja (w) polityce. Polityka (w) edukacji. Inspiracje do badań polityki oświatowej, OW Impuls, Kraków 2015, p. 26.

${ }^{3}$ M. Warnock, Special Educational Needs. Report of the Committee of Enquiry int Education of Handicapped Children and Young People, London: HMSO 1978. 
turn, since the half of the 1990s, due to the arrangements made in the Salamanca Statement for Action and Framework for Action on Special Needs Education ${ }^{4}$, regarding to the directives in the area of special educational needs, a process has begun, dedicated to the prevention of educational exclusion, which, in short, led to the ratification of the Convention on the Rights of Persons with Disabilities in 20065. The actions were made possible due to discarding the medical model of disability for the sake of constituting a social model. The aforementioned changed not only the way of defining the key terms within the matter, in order to reduce stigmatisation, but, primarily, to identify the needs, and to support, educate, and realise the social roles of persons, i.a. with disabilities. Formally, in Poland, the trend has begun, i.a. in the educational practice, however, a moment later, since the half of the 1990s ${ }^{6}$. Even later on, the education of staff at the level of higher education began to answer the needs in this area.

\section{The project of own research}

The research results, presented here, are a part of a broader project dedicated to the opinions of teachers from various educational establishments, and from various phases of education, regarding the inclusive education.

4 Deklaracja z Salamanki oraz wytyczne dla działań w zakresie specjalnych potrzeb edukacyjnych, UNESCO 1994 https://rownosc.info/.../deklaracja-z-salamanki-orazwytyczne-dla-d... [access: 8.02.2019].

${ }^{5}$ Convention on the Rights of Persons with Disabilities, United Nations New York: United Nations 2006, http://www.un.ogr/disabilities/convention/conventionfull. shtml [access: 20.02.2019].

${ }^{6}$ E.g. The 4 October 1993 MEN Regulation No. 29 on the rules of care regarding students with disabilities, their education in mainstream and integrated public preschools, schools and establishments, as well as, establishments special education, Journal of Laws No. 19, pos 167 (Zarządzenie Nr 29 MEN z dn. 4 października 1993 r. w sprawie zasad organizowania opieki nad uczniami niepełnosprawnymi, ich kształcenia w ogólnodostępnych i integracyjnych publicznych przedszkolach, szkołach i placówkach oraz organizacji kształcenia specjalnego, Dz.U. No. 19, pos. 167). 
The aims of the project presented here are as follows:

1. to learn the attitudes and the opinions of the teachers on varying levels of seniority, from special pre-schools, regarding the benefits resulting from inclusive education for the generalised groups of the participants of the process of education, i.e. children: without special needs, and with special needs, however, displaying certain aptitudes;

2. to identify, whether essential statistical differences exist in the opinions of teachers, determined by their seniority, regarding the chances of the success of the inclusive actions for twelve homogeneous groups of children with disorders and development disruptions: intellectual disability, hearing-impaired, deaf, blind, with autism, with the Asperger syndrome, with a physical disability, a multiple disability, communication disorders, as well as, with a chronic condition.

The selection of the control group - among the teachers from special pre-schools -within the context of the considerations regarding inclusive education, can be substantiated.

First - it results from the experience of the teachers of special establishments, regarding the cooperation with a child/student with a disability. Teachers from establishments of different kinds, e.g. integrated and mainstream ones, possess no such experience. In combination with the second argument - larger, at least in the formal sense, competencies regarding the profiled education regarding special pedagogy (the formal requirement for the employment in a particular type of an educational establishment) 7 , one may assume that the teachers from special establishments possess a more comprehensive knowledge regarding the needs and educational capabilities of this group of children/students, than the mainstream establishments' teachers, which is confirmed by the analyses per-

7 The 1 March 2019 regulation of the Minster of National Education, changing the regulation regarding detailed qualifications required from the teachers, Journal of Laws - 11 March 2019, pos. 465. (Rozporządzenie Ministra Edukacji Narodowej z dnia 1 marca 2019 r. zmieniające rozporządzenie w sprawie szczegółowych kwalifikacji wymaganych od nauczycieli, Dz. U. z dnia 11 marca 2019 r., poz. 465.) 
formed, i.a. by Zenon Gajdzica ${ }^{8}$, or Grzegorz Szumski ${ }^{9}$. Therefore, knowing their opinions may help in recognising the necessary areas of supporting the child/student, and its launch as soon as possible (an argument for the realisation of research among the group of preschool education teachers), in order to optimise the chances of success of the actions.

Another determinant is, as it seems, related to the scepticism in the evaluation of inclusive education as a systemic solution, in education of children/students with disabilities, and special educational needs; scepticism that is higher in comparison to teachers from other educational establishments ${ }^{10}$. Meanwhile, one of the rational determinants of the success of every action, especially performed on a macro-scale, is the consent regarding its reasonableness, its benefits, an agreement and cooperation in striving to overcome the possible barriers, that must always be taken into account, the capabilities of children/students, as well as, the conditions, the assets of educational establishments, and, often, the environmental conditions of their functioning. There is an additional, significant reason for learning the special pre-school teachers' opinions, regarding the chances of success of the inclusive education for students with disabilities, or special educational needs - it is a specific "mapping" of the fields of necessary support for children/students with disabilities, as well as, for their parents, and the teachers, already at the initial phase of educational actions, for the purpose of realising, with success, a finalised process of educational inclusion, and the collective

8 Z. Gajdzica, Opinie nauczycieli szkót ogólnodostępnych na temat edukacji właczającej uczniów z lekkim upośledzeniem umystowym w kontekście toczacej się reformy kształcenia specjalnego, [w:] Uczeń z niepetnosprawnością w szkole ogólnodostępnej, red. Z. Gajdzica, OW „Humanitas”, Sosnowiec 2011.

${ }^{9}$ G. Szumski, Wokót edukacji wtaczającej. Efekty ksztatcenia uczniów z niepetnosprawnościa intelektualna $w$ stopniu lekkim w klasach specjalnych, integracyjnych $i$ ogólnodostępnych, współpraca A. Firkowska-Mankiewicz, Wydawnictwo APS, Warszawa 2010.

${ }^{10}$ I. Chrzanowska, Nauczyciele o szansach $i$ barierach edukacji wtaczajacej, PWN, Warszawa 2019, p. 129 and further. 
education of students within the inclusive classroom/school space. Additionally, it is worth referring directly to why it is worth, or even necessary recognising the attitudes, beliefs or opinions of teachers regarding inclusive education in regard to children/students with disabilities. In order to show, that it is not based on the author's belief, one may recall the constatation of, e.g. Zenon Gajdzica, who indicates that "at the level of implementation (of the idea - ed.), the most important element determining the efficiency of the designed changes is the teachers. It is their involvement and beliefs, that decide on the eventual success, and the manifested opposition explicitly impedes, or even prevent the effective implementation of reforms"11.

The teachers' seniority was included among the essential variables of the performed analyses. It seems essential to recognise this determinant, i.a. within the context of the aforementioned essential changes that, in recent years, have become the basis for recommending and implementing the solution which is inclusive education. The commitment of the Convention on the Rights of the Persons with Disabilities (Konwencja o prawach osób niepetnosprawnych), ratified in 2012, obligates to undertake decisive and efficient actions related to creating conditions for the realisations of the inclusive policies, also in the educational sector, which indubitably, is an effect of the paradigmatic change in the approach towards disability ${ }^{12}$.

It would be incorrect to infer, that teachers with lower seniority do, whereas the teachers with higher seniority do not, posses an awareness of the change of the theoretical model of the inquiries regarding disability, or special educational needs; as one should remember, that teaching is among professions that require continuous supplementation and expansion of competencies, as well as,

11 Z. Gajdzica, Opinie nauczycieli szkół ogólnodostępnych na temat edukacji włączajacej uczniów z lekkim upośledzeniem umysłowym w kontekście toczacej się reformy kształcenia specjalnego, [w:] Uczeń z niepetnosprawnością w szkole ogólnodostępnej, (ed.) Z. Gajdzica, OW „Humanitas”, Sosnowiec 2011, p. 60.

12 A. Krause, Wspótczesne paradygmaty pedagogiki specjalnej, OW Impuls, Kraków 2010. 
acquisition and update of knowledge. Additionally, one should remember about the determinants of the attitudes, among which the scholars list: knowledge, sex, age, cultural influence, as well as, the influence of the basic social groups ${ }^{13}$. In accordance with the established knowledge, within the context of identifying the determinants of shaping opinions, beliefs, or attitudes, one must refer to three key components: behavioural, affective, and cognitive ${ }^{14}$.

No doubt, that which differentiates both groups of teachers participating in the research, is age and experience, probably larger among persons that have remained in their profession longer.

The determinants listed above allow to pose a thesis regarding a possible diversity of attitudes towards the idea of inclusive education, among teachers, depending on their seniority. Within the context of the inquiries posed here, it is essential to realise that the attitudes and beliefs regarding inclusive education regarding children with disabilities, manifested by special pre-school teachers depending on their seniority, are worth identifying. In the case of teachers with a shorter work time, it is a determinant of a potential, perennial perspective of shaping the reality of the realisation of the idea of joint education. In the case of the more experienced teachers (with longer seniority) - it is essential from the viewpoint of the support of inclusive education.

Two research instruments were used. The first one, a proprietary questionnaire, referred to the opinions of teachers regarding, whether they find inclusive education to be a beneficial educational solution for all the participants of the process of education, therefore, the children/students: able ones; with special educational needs resulting from developmental disorders and disruptions; with special educational needs - but gifted. The examined could check

${ }^{13}$ T. Mądrzycki, Psychologiczne prawidłowości ksztattowania się postaw, WSiP, Warszawa 1997.

14 S. Mika, Psychologia społeczna, PWN, Warszawa 1987; T. Mądrzycki, Psychologiczne prawidłowości kształtowania sie postaw, WSiP, Warszawa 1997; L.R. Aiken, Attitudes and Related Psychosocial Constructs. Theories, Assessment and Research, Sage Publications, Inc., Thousand Oaks, London-New Delhi 2002. 
one of the three answers: yes, no, I do not know/I do not have an opinion. The inference in this area was based structure indicators. The second instrument was dedicated, in an expanded way, to the students with developmental disorders and disruptions, in inclusive education. Twelve homogeneous groups were distinguished, and among them, children/students with: mild intellectual disability, moderate and severe intellectual disability, hearing-impaired, deaf, visually-impaired, blind, with autism, with the Asperger syndrome, with physical disability, with multiple disabilities, with communication disorders, and with chronic conditions, regarding to which, the examined were tasked to express their own opinions regarding the chances of success of the inclusive education. The answers were set on a scale from 5 to 1 , where 5 meant - very high chances of the success of the actions, 4 - high chances, 3 - moderate, 2 - low chances, 1 - no chances of success of inclusive actions.

127 special pre-school teachers participated in the research, mostly from the areas of the Voivodeships: the Greater Poland Voivodeship, the Masovian Voivodeship, the Łódź Voivodeship, and the Lower Silesia Voivodeship. The rather unusual division of seniority groups into teachers with 10 or less years of experience, and teachers with more than 10 years of experience, demands an explanation. In reality, one could present it in quite a different configuration: teachers with 10 or less years of experience, and teachers with more than 20 years of experience, as these two groups definitely prevailed among the examined, selected, what is essential, randomly (after expressing their consent regarding the participation in the research). The first option was chosen in order to present the opinions of all the teachers participating in the research, among which c. $94.5 \%$ were women.

It turns out that in the analyses performed on a much larger scale, such distribution of seniority was not surprising. Scholars indicate, that the age profile of the teachers is an increasingly severe issue in education, surely not in Poland only. The results of the data gathered from 25 EU countries, show that almost in a number of countries, the prevalent number of teachers are of pre-retirement 
age, or are soon to receive privileges in that aspect. Therefore, in numerous educational systems, on many positions, teachers are already replaced by the representatives of similar professions, realising various roles at schools ${ }^{15}$. Obviously, an issue appears, regarding their preparation for working with students, but also another, more significant of an axionormative nature. It is of particular importance regarding pedagogues/teachers who work at special establishments, i.e. with children/students with severe developmental disorders. As indicated by Piotr Plichta, who refers to the analyses of Debra W. Emery and Brian Vandenberg ${ }^{16}$ the special teacher-pedagogue profession is a specific risk profession. It is unique, as the situations which the pedagogues-teachers face at work, are unique as well. The professional contact with unique persons, complex issues, atypical behaviour, and coexisting dysfunctions, is such a rare experience, that the persons who perform this type of work seem to experience a certain kind of isolation, or decide to isolate by themselves. In certain situations, as indicated by Plichta, "at times it is really difficult to answer the question: How's work?"17. It seems, that special pedagogues-teachers still arouse interest with their "specific" profession. Despite the increasing presence of the issues of disability within the social areas, many, including teachers, have not encountered students with disabilities at work, and, with high probability, with a student with a severe or complex disability. Therefore, the special pedagogues carry an exceptional responsibility for both their professions, but, primarily, for the persons they work with. For only through the promotion of a positive image of a person with a disability, it is possible to increase his/her chances of participating in the social life. The spe-

15 European Agency for Special Needs and Inclusive Education, Ksztatcenie nauczycieli przygotowujace do edukacji właczajacej w Europie - Wyzwania $i$ szanse, EAREU ze SPE, Odense, Dania 2011, p. 76.

16 D.W. Emery, B. Vanderberg (2010) after: P. Plichta, Wypalenie zawodowe i poczucie sensu życia pedagogów specjalnych, Oficyna Wydawnicza ATUT - Wrocławskie Wydawnictwo Oświatowe, Wrocław 2015, p. 26.

17 P. Plichta, Wypalenie zawodowe i poczucie sensu życia pedagogów specjalnych, OW ATUT - Wrocławskie Wydawnictwo Oświatowe, Wrocław 2015, p. 26. 
cifics of this profession lie in its interdisciplinary nature. It is no solely a didactic work with a student, but also a continuous work on own competencies, as the student most often requires constant support, complex rehabilitation, working on social inclusion for the normalisation of own life situation. Many times, it is related to the necessity of supporting the family and the environment, working or the cooperation with specialists. This sketchy characteristic already indicates, that in order to responsibly and efficiently cooperate with a child/student with a disability in the process of education, a number of high end extant competencies are required, including, particularly, the personal competencies related to a specified system of values and strong inner motivation.

Additionally, one should realise that currently, it generally applies to all teachers, as the theory of inclusive education assumes, that in mainstream schools, the presence of students with developmental disorders will be even higher than until recently. There is one conclusion - the best graduates should be recruited for the teacher-pedagogue profession, only the best candidates should be admitted to universities, and the main indicator should not be the sum of points of high-school examination, but also other competencies. The aforementioned occurs in certain countries. Few, as they are the most wealthy, as it requires excellent work conditions.

In the majority of cases, the issues that the countries face during recruitment, education and staying within the profession of the staff, are similar. They are reduced to a constatation, that the teacher's profession should rebuild its status and social respect, bringing back the image of a pedagogue as the leading intellectual, and not simply a "provider of someone else's ideas". Anne Moran indicates, that teachers who concentrate solely on the methods of teaching and the standards of education, without involving in social and moral issues of their time, reinforce the "impaired" image of a teacher, and their profession ${ }^{18}$.

18 A. Moran, Can a competence or standards model facilitate an inclusive approach o teacher education? „International Journal of Inclusive Education”, 13(1), pp. 58-59, 45-61. 
The specific deprecation of the teacher-pedagogues profession results partially and paradoxically from the enrolment rate increase. In 1990 , it was $9,8 \%$, to reach $40,9 \%$ in 200919 . The trend, initiated in the 1990s, related to the ability of gaining higher education beyond public universities, resulted in a dynamic increase of the number of universities in Poland. According to the data of the Ministry of Science and Higher Education (Ministerstwo Nauki i Szkolnictwa Wyższego - MNiSW), of 2009/2010, there were more than 450 (457) universities at the time, with 326 private ones. In comparison, in 1992/1993 there were 124 universities, including 18 private ones. Pedagogy was the third degree, in terms of popularity, chosen by c. $12 \%$ of students. Pedagogy was present at 17 Universities, 6 Pedagogical Higher Education Schools, as well as, at Universities of Technology (e.g. the Koszalin Institute of Technology, or the Radom Institute of Technology) ${ }^{20}$. As a degree, it was held at 97 highereducation schools (i.a. The Schools of: Economy, Trade, Mercantile, Security, Strategical Planning) ${ }^{21}$. Special pedagogy was less popular, at the time it was present at 10 higher education schools (amounting to a $3,1 \%$ ). This way, a large amount of pedagogues appeared on the market, including many teachers, and not everyone could find employment in accordance with their education. Of course, there were bright sides about this, regarding the interest of the educational establishments, as truly one could choose the best candidate. A different question is, what happens within the area of the competencies of the pedagogical degrees' graduates during such a dynamic increase in the interest in this degree, resulting - from staff shortages (of academic teachers) - in the increase of the number of class groups, not to mention the lectures, which were often held for several-hundred groups.

19 Szkolnictwo wyższe w Polsce, Ministerstwo Nauki i Szkolnictwa Wyższego, Warszawa 2013, p. 6.

20 http:/ / mmkoszalin.eu/artykul/nowy-kierunek-pedagogika-na-politechnicekoszalinskiej-180164.html; http://www.uczelnie.info.pl/index.php?mod=uczelnie \&pokaz $=288$

21 (http:/ / www.nauka.gov.pl/szkolnictwo-wyzsze/ system-szkolnictwa-wyzsze go/uczelnie/uczelnie-niepubliczne/wykaz-uczelni-niepublicznych/) 
Currently, a different issue of teacher education in Poland is the decreasing number of students, related to the population decline. Since 2006/2007 the number of students in Poland has dwindled systematically22. The MNiSW data indicate, that the decrease will last at least until 2025, and in 2034 it will reach a level comparable to that from 2016/2017 (c. 1 million 480 thousand). ${ }^{23}$. Additionally the analyses indicate that a systematically decreasing number of candidates will apply for pedagogical degrees. In the 2007-2011 period, their number decreased by $2,8 \%$, and it was the third greatest decrease among educational subgroups (following: defence and security, and economy and administration) ${ }^{24}$.

Within the context of the previous thesis, regarding the necessity of recruiting for the degree and to recruit the best candidates and graduates to the profession, it is worth noting, that among the 19 most popular degrees chosen by the winners of the high-school contests in the academic year 2012/2013, pedagogy was not present ${ }^{25}$.

\section{Research results, discussion}

Within the context of the first aim of the research - identifying the opinion and beliefs determined by the seniority of the special pre-school teachers, regarding whether inclusive education is a beneficial solution for all groups of children/students, the participants of the process - one may indicate, that in reference to all groups, teachers with lower seniority, are a larger group that perceives inclusive education as a beneficial solution.

In the case of children/students without special needs, $76,5 \%$ teachers from the pre-school education phase, from special establishments, with seniority of 10 or less years, and $67 \%$ of teachers

\footnotetext{
22 Szkoły wyższe i ich finanse w 2014 r., Warszawa, GUS 2015, p. 26.

23 Ibidem, p. 8.

24 Szkolnictwo wyższe... 2013, p. 17.

25 Ibidem, p. 24.
} 
with more than 10 years, acknowledge, that inclusive education is a good solution. However, simultaneously, twice as many teachers with higher seniority, perceive this theory as unfavourable to the student (respectively: 11: 11,8\% - teachers with 10 or less years, and $22,4 \%$ teachers with more than 10 years of experience). Almost equinumerous groups of examined are unable to formulate an explicit opinion on the matter. A slightly larger difference of opinion, can be observed in the results of the research regarding the same issue, but within the context of gifted students. 76,5 of teachers participating in the study, with 10 or less years of experience, and $60,5 \%$ of teachers with more than 10 years of experience, evaluate the proposition of joint education positively, regarding the benefits that the gifted student may gain. The differentiation of opposing opinions is even more explicit than in the case of the previous group, respectively: $11,8 \%$ - teachers with a seniority of 10 or less years, and almost $1 / 4$ of the seniority group above 10 years.

Table 1. The opinions of special pre-school teachers regarding the educational opportunities of particular student groups in inclusive education, and the seniority (values given in \%)

\begin{tabular}{|l|c|c|c|c|c|c|c|c|c|}
\hline \multirow{3}{*}{ Seniority } & \multicolumn{8}{|c|}{ Child in inclusive education } \\
\cline { 2 - 10 } & $\begin{array}{c}\text { Child without } \\
\text { special needs }\end{array}$ & \multicolumn{2}{c|}{$\begin{array}{c}\text { Child with SEN } \\
\text { (except a gifted child }\end{array}$} & \multicolumn{3}{c|}{$\begin{array}{c}\text { Child with SEN - } \\
\text { gifted child }\end{array}$} \\
\cline { 2 - 10 } & $\mathrm{Y}$ & $\mathrm{N}$ & $\mathrm{IDK}$ & $\mathrm{Y}$ & $\mathrm{N}$ & $\mathrm{IDK}$ & $\mathrm{Y}$ & $\mathrm{N}$ & IDK \\
\hline 10 or less years (Y=51) & 76,5 & 11,8 & 11,7 & 76,4 & 11,8 & 11,8 & 76,5 & 11,7 & 11,8 \\
\hline $\begin{array}{l}\text { More than 10 years } \\
(\mathrm{N}=76)\end{array}$ & 67,1 & 22,4 & 10,5 & 38,2 & 60,5 & 1,3 & 60,5 & 26,3 & 13,2 \\
\hline
\end{tabular}

Description: $\mathrm{Y}$ - yes (inclusive education is a good solution for the child); $\mathrm{N}$ - no (inclusive education is not a good solution for the child; IDK - I don't know, I don't have an opinion (whether inclusive education is a good solution for the child)

The largest differentiation, however, is related to the education within the framework of inclusive education of children/students with special needs, endangered with or displaying development disorder. In the case of the teachers from the first seniority group, 
the benefits for the student are noted by $76,4 \%$ of the teachers, with only $38,2 \%$ of the teachers that are more experienced. Additionally, the teachers of higher seniority, are exceptionally explicit in their opinions. Only a bit over 1\% of the teachers could not form a clear opinion between yes and no for inclusive education for students with special educational needs, endangered or displaying developmental disorders and disruptions. More than $60 \%$ of special preschool teachers is against inclusive education regarding this group of children/students.

One should remember, that in accordance with the letter of law, among the children/students with special educational needs, there are also those that have severe disabilities, and multiple disabilities. More experienced teachers (more than 10 years) seem to say a clear no to the "total" inclusive education, regardless of the type, and particularly, the level of disability.

A confirmation of the fact may be found in the case of the analysis of the results of the research related to the opinions of teacher regarding the educational opportunities within the framework of common learning for particular groups of students with developmental disorders and disruptions, determined by their seniority.

First, one should notice, that the teachers with 10 or less seniority, see opportunities in inclusive education as very high, however, solely in reference to children/students with physical disability. The six following groups: with mild intellectual disability, hearingimpaired, visually-impaired, with the Asperger syndrome, with communication disorders, and with chronic conditions - as high, while the remaining five groups, including: with moderate and severe disability, deaf, blind, with autism and with multiple disability as low. The lowest results were achieved in reference to children/students with moderate and severe intellectual disability and students with autism.

The opinions of teachers with higher seniority present differently. First of all, no group was evaluated as very high. Eight groups were indicated by teachers with more than 10 years of experience, as having high chances of success of the inclusive actions. These include 
children/students: with mild intellectual disability, hearing-impaired, visually-impaired, with autism, with the Asperger syndrome, with physical disability, with multiple disability, and with a chronic condition. The chances of the remaining four groups were evaluated as low. The highest score, indicating the highest opportunities within the framework of inclusive education (adequately to the range of average results) was noted in the case of students with a chronic condition, the lowest in the case of students with moderate and severe intellectual disability.

Looking at the range of results, one may assume that the opinions of teachers from both groups are similar. Teachers of lower seniority

Table 2. The opinions of special pre-school education teachers regarding the chances of success of inclusive actions regarding various groups of children/students with developmental disabilities and disruptions, and the seniority

\begin{tabular}{|l|c|c|c|c|c|c|}
\hline & \multicolumn{2}{|c|}{$\begin{array}{c}\text { Seniority 10 } \\
\text { or less years } \\
(\mathrm{N}=51)\end{array}$} & $\begin{array}{c}\text { Seniority more } \\
\text { than 10 years } \\
(\mathrm{N=76})\end{array}$ & $\begin{array}{c}\text { Student's } \\
t \text {-test }\end{array}$ & p.i \\
\cline { 2 - 9 } & $\mathrm{M}$ & $\mathrm{S}$ & $\mathrm{M}$ & $\mathrm{S}$ & & \\
\hline Mild intellectual disability & 3,65 & 0,88 & 3,0 & 1,22 & 3,283 & 0,001 \\
\hline Moderate and severe intellectual disability & 2,53 & 0,89 & 1,89 & 1,06 & 3,232 & 0,001 \\
\hline Hearing-impaired & 3,65 & 0,74 & 3,29 & 0,62 & 2,687 & 0,01 \\
\hline Deaf & 2,88 & 0,65 & 2,13 & 0,86 & 4,808 & 0,001 \\
\hline Visually-impaired & 3,49 & 0,75 & 3,13 & 0,55 & 2,835 & 0,01 \\
\hline Blind & 2,65 & 0,88 & 2,41 & 0,93 & 1,319 & n.is \\
\hline Autism & 2,53 & 0,7 & 3,2 & 0,97 & $-3,851$ & 0,001 \\
\hline Asperger syndrome & 3,22 & 0,8 & 3,87 & 1,02 & $-3,476$ & 0,001 \\
\hline Physical disabilities & 4,22 & 0,64 & 3,87 & 0,94 & 2,108 & 0,05 \\
\hline Multiples disability & 2,77 & 1,06 & 2,89 & 1,33 & $-0,489$ & n.is \\
\hline Communication disability & 3,14 & 0,86 & 3,04 & 1,18 & 0,472 & n.is \\
\hline Chronic condition & 3,55 & 0,91 & 3,95 & 0,99 & $-2,094$ & 0,05 \\
\hline
\end{tabular}

Description: the explanations regarding the interpretation of the results: results in the 1-1,99 range - no chances of success in inclusive education regarding the given group of students, 2-2,99 - low chances, 3-3,99 - high chances, 4-5 - very high chances; $\mathrm{M}$ - Arithmetic Mean; $\mathrm{S}$ - Standard Deviation 
evaluated the chances of one group as very high, which was not present in the other group. However, it was the more experienced teachers who selected more groups of children/students as having low chances, than the teachers with lower seniority (respectively: 4 and 5 groups).

Only the comparison of the study results reveals that there appear, and in the majority of cases are significant, differences in the opinions among the examined teachers. These relate to children/students: with mild intellectual disability, with moderate and severe intellectual disability, hearing-impaired, deaf, visuallyimpaired, and with physical disability - in these cases the teachers with lower seniority are more optimistic in foreseeing the chance of success of the inclusive actions. In reference to the three remaining groups of children/students: with autism, with the Asperger syndrome and with a chronic condition, it is the teachers with higher seniority that seem to see the chances of these groups of children/students with special educational needs in inclusive education, as higher. There are no statistically significant differences, meaning both groups agree in the case of the evaluation of the chances of the children/students: blind, with multiple disability and with communication disorders. Generally, one should also highlight, that the higher consistency of opinions can be seen between teachers with lower seniority, the standard deviation in reference to nine out of twelve groups of children/students is lower, than in the case of the teachers from the other group.

\section{Summary}

- Special pre-school teachers with 10 or less years of seniority seem to see more chances in inclusive education, than the more professionally experienced teachers.

- $3 / 4$ (c. $75 \%$ ) of the examined teachers working for 10 or less years, assume that inclusive education is a beneficial solution for every group of students: without special needs, with special 
needs endangered with, or displaying developmental disorders and disruptions, as well as, students with special needs that display aptitudes.

- Teachers with higher seniority are more sceptical to each of the listed groups. The smallest differences are associated with the students without special needs. Only less than $10 \%$ percent of teachers with higher seniority, than those of the lower seniority, evaluate the inclusive education as a beneficial solution for this group of students. In the case of the remaining two, the increased scepticism of the teachers with higher seniority is already clearly visible, particularly in reference to the students with special needs endangered with, or displaying developmental disorders and disruptions. Only 38\% of the examined special pre-school teachers (within this seniority group) find inclusive education to be a beneficial solution for schooling children/students with developmental disorders and disruptions.

- A detailed analysis in reference to the distinguished groups of students with special needs, displaying developmental disorders confirms their higher scepticism related to the expectation, that the participation in common education is an opportunity for the child/student.

- In the case of six groups of students, it is the lower seniority teachers who assume the chances of students as higher (that applying to persons: with mild intellectual disability, moderate and severe intellectual disability, hearing-impaired, deaf, visually-impaired, with physical disorders), in three cases the higher seniority teachers are more optimistic (that applying to persons: with autism, with the Asperger syndrome, and with a chronic condition), while in the remaining three groups, the examined teachers' opinions do not differ significantly.

There are too few reports regarding research that would focus on the spectrum analysed here, and in reference to the special preschool teachers and their seniority. Most often, within the context of inclusive education, the mainstream establishments teachers' opin- 
ions, attitudes and beliefs were recognised. An overview of such research can be found, e.g. in a publication by Beata Cytowska ${ }^{26}$. Searching for explanations for the increased scepticism of teachers with seniority higher in comparison with the second group, one may think that it might result from the lack of faith in actual changes, after the announcements of their implementation. For many years, the educational sector has been underfunded. In comparison with the requirements and the professional strain the wages and the expenditures in support of the student and the teacher are low. In comparison to international studies, the Polish teachers have an average lower feeling of being supported in their professional development, that also being related to their own costs of professional training 27 . A range of modifications introduced in education, within the context of inclusion, starting with the creation of classes and integrated units, did not meet the expectations. At least a part of the children/students with developmental disorders and disruptions, after some time at integrated and inclusive establishments, still return to special schools. The aforementioned is supported by research results, e.g. Institute of Educational Research (Instytut Badań Edukacyjnych - IBE) 2014 study indicating that there is an outflow of children, with opinions regarding the necessity of special schooling, from mainstream and integrated schools, to special schools ${ }^{28}$. The parents change the schooling establishment of their child as well, and that being already during the pre-school education. Among the most common reasons are, e.g. the establishment not being adjusted to the needs of the child $(19,9 \%)$, the lack of support for the children and his/her poor relations with the peers $(10,9 \%)^{29}$.

26 B. Cytowska, Przeglad badań empirycznych nad inkluzja w edukacji, „Problemy Edukacji, Rehabilitacji i Socjalizacji Osób Niepełnosprawnych” 22/1, 2016, pp. 189-213.

${ }^{27}$ K. Hernik, K. Malinowska, R. Piwowarski, J. Przewłocka, M. Smak, A. Wichrowski, Polscy nauczyciele i dyrektorzy na tle międzynarodowym. Główne wyniki badania TALIS 2013, IBE, Warszawa 2014, p. 27.

28 P. Grzelak, P. Kubicki, M. Orłowska, Realizacja badania ścieżek edukacyjnych niepetnosprawnych dzieci, uczniów i absolwentów. Raport końcowy, IBE, Warszawa 2014.

29 P. Grzelak et al., 2014, p. 42. 
One may assume, that during a longer period of time working within the profession, the teachers face such situations more often than if they had remained at their position for less time. Additionally the prolonged period of working in the profession, gives teachers the opportunity to observe the trends, subsequent "ideas" to cope with marginalisation, educational exclusion, e.g. due to the fact of disability. If they are inconspicuous, if little changes despite the announcements and promises - one shouldn't wonder at the scepticism of the teachers.

One may also consider, whether the difference in the attitudes of the special pre-school teachers should be explained e.g. by the professional burnout phenomenon. The results of Piotr Plichta's studies show that the level of the emotional exhaustion of special pedagogues grows along with their seniority, similar as the feeling of achievement. In the case of depersonalisation, the lowest rates occur in cases of special teachers-pedagogues with the highest seniority, while the highest occur among teachers with the middle-range seniority ${ }^{30}$. Therefore, maybe the special teachers and pedagogues with higher seniority perform a certain transfer of own experiences, which may be of significance for their own opinions and attitudes regarding inclusive education and its realisation although mainly, the teachers from mainstream establishments will be more prone to them. Within the context of emotional exhaustion, growing with every year of own work, special teachers and pedagogues may fear that the teachers from mainstream establishments will be much more prone to it. The aforementioned may be supported by the fact that, as indicated by the studies' results - the teachers from mainstream schools believe that their competencies are low, insufficient for working with a student with a disability ${ }^{31}$. Therefore, the feeling of competency will not "protect" the inclusive establishments'

30 Seniority groups in P. Plichta's study: 8 years or less, 8 years to 21 years, and more than 21 lat, P. Plichta, 2015, pp. 116-117.

31 E.g. G. Szumski 2010, Z. Gajdzica 2011, M. Chodkowska, Z. Kazanowski, Socjopedagogiczne konteksty postaw nauczycieli wobec edukacji integracyjnej, Wydawnictwo UMCS, Lublin 2007. 
teachers in the case of the feeling of achievement. It may also further the depersonalisation of students. Of course that is, to a large degree, speculation. Other explanations of the least beneficial study results among the special pre-school teachers with higher seniority, regarding inclusive education. Within the context of inclusive education, one should assume two solutions. First - the success of the idea, causing that all children will be able to educate themselves successfully, in a pre-school/school that is in the closest proximity of their home, most often meaning a mainstream school, regardless of whether they experience or do not experience disabilities/special educational needs, which in time would result in shutting down integrated and special educational establishments. The second solution - the fiasco of the idea and, as a result, remaining with the current solution - the existence of various types of pre-schools/schools, including those dedicated to children/students with a particular type, or even a particular degree of disability. In the first case, shutting down special schools is a potential threat of unemployment to the teacher, particularly when the potential systemic proposals for this professional group are unknown. If, and how many teachers of current special current establishments will find employment in mainstream schools, and at what position? What will be their professional status? Teachers with higher seniority may perceive it as a threat to their own professional stability. The experience of the still unfavourable situation of a student with disability in the social environment, including the educational one, and resulting from social attitudes, the lack of understanding, and the lack of acceptance for being different, may also be significant for the scepticism of the teachers with higher seniority. The very fact of the appearance of an idea of common education, provides evidence that the issue of the marginalisation of persons with disabilities is noticed, however, there are still numerous stereotypes associated with disabilities and with the persons that experience them. From this perspective - the slow change of attitude - the teachers from special schools may fear, that the student, in result of common education in a mainstream school, may experience antipathy from his peers, and even isolation, 
or rejection. The scientific studies in this area, clearly indicate such a threat ${ }^{32}$.

The study results confirmed the differentiated opinions of the examined special pre-school teachers of varying levels of seniority, regarding inclusive education, within the presented context. Additionally, it seems that the analyses should be expanded with profound studies of their causes, at least these mentioned above. Unfortunately, it was not accomplished in the presented project, and maybe they would aid us in explaining the varying attitudes, therefore, diagnosing the necessary areas of support both for the child/student, and the teacher in the process of education.

\section{Bibliography}

Aiken L.R., Attitudes and Related Psychosocial Constructs. Theories, Assessment and Research, Sage Publications, Inc., Thousand Oaks, London-New Delhi 2002.

Chodkowska M., Problemy pedagogicznego wsparcia uczniów z niepetnosprawnościa intelektualna $w$ zakresie społecznego funkcjonowania w klasie szkolnej, in: Wsparcie społeczne w rehabilitacji i resocjalizacji, (ed.) Z. Palak, Wydawnictwo UMCS, Lublin 2004.

Chodkowska M., Kazanowski Z., Socjopedagogiczne konteksty postaw nauczycieli wobec edukacji integracyjnej, Wydawnictwo UMCS, Lublin 2007.

32 E.g.: M. Chodkowska, Problemy pedagogicznego wsparcia uczniów z niepetnosprawnościa intelektualna w zakresie spotecznego funkcjonowania w klasie szkolnej, in: Wsparcie spoteczne w rehabilitacji i resocjalizacji, (ed.) Z. Palak, Wydawnictwo UMCS, Lublin 2004; K. Ćwirynkało, M. Wójcik, Integracja osób petno- $i$ niepetnosprawnych a postawy nauczycieli wobec integracji, $\mathrm{w}$ : Integracja osób niepetnosprawnych w edukacji $i$ integracjach spotecznych, (eds.) Z. Kazanowski, D. Osik-Chudowolska, Wydawnictwo UMCS, Lublin 2003; A. Maciarz, Integracja edukacyjna w świetle doświadczeń i oczekiwań dzieci niepetnosprawnych, in: Dziecko ze specjalnymi potrzebami edukacyjnymi w ekosystemie, (eds.) W. Pilecka, A. Ozga, P. Kurtek, Wydawnictwo AŚ, Kielce 2005; A. Maciarz, Stosunki społeczne między uczniami petnosprawnymi i upośledzonymi umystowo, w: Wychowanie, ksztatcenie i przygotowanie do życia dzieci upośledzonych umystowo. Materiaty z konferencji naukowej (Kraków 16-17 maja 1984), (eds.) J. Baran, J. Pilecki, Wydawnictwo WSP, Kraków 1985. 
Chrzanowska I., Nauczyciele o szansach i barierach edukacji wtaczającej, PWN, Warszawa 2019.

Convention on the Rights of Persons with Disabilities, United Nations New York: United Nations 2006, http://www.un.ogr/disabilities/convention/conventionfull.shtml [access: 20.02.2019].

Cytowska B., Przegląd badań empirycznych nad inkluzja w edukacji, „Problemy Edukacji, Rehabilitacji i Socjalizacji Osób Niepełnosprawnych" 22/1 2016, pp. 189-213.

Ćwirynkało K., Wójcik M., Integracja osób petno- $i$ niepetnosprawnych a postawy nauczycieli wobec integracji, w: Integracja osób niepetnosprawnych w edukacji i integracjach społecznych, (eds.) Z. Kazanowski, D. Osik-Chudowolska, Wydawnictwo UMCS, Lublin 2003.

Deklaracja z Salamanki oraz wytyczne dla dziatań w zakresie specjalnych potrzeb edukacyjnych, UNESCO 1994 https://rownosc.info/.../deklaracja-z-salamankioraz-wytyczne-dla-d... [access: 8.02.2019].

Europejska Agencja Rozwoju Edukacji Uczniów ze Specjalnymi Potrzebami, Ksztatcenie nauczycieli przygotowujące do edukacji wtaczajacej w Europie - Wyzwania $i$ szanse, EAREU ze SPE, Odense, Dania 2011.

Gajdzica Z., Opinie nauczycieli szkót ogólnodostępnych na temat edukacji włączającej uczniów z lekkim upośledzeniem umystowym w kontekście toczącej się reformy ksztatcenia specjalnego, w: Uczeń z niepetnosprawnościa w szkole ogólnodostępnej, red. Z. Gajdzica, OW „Humanitas”, Sosnowiec 2011.

Grzelak P., Kubicki P., Orłowska M., Realizacja badania ścieżek edukacyjnych niepetnosprawnych dzieci, uczniów i absolwentów. Raport końcowy, IBE, Warszawa 2014.

http://mmkoszalin.eu/artykul/nowy-kierunek-pedagogika-na-politechnice-kosza linskiej-180164.html

http://www.uczelnie.info.pl/index.php?mod=uczelnie\&pokaz $=288$

(http://www.nauka.gov.pl/szkolnictwo-wyzsze/system-szkolnictwa-wyzszego/ uczelnie/uczelnie-niepubliczne/wykaz-uczelni-niepublicznych/).

Hernik K., Malinowska K., Piwowarski R., Przewłocka J., Smak M., Wichrowski A., Polscy nauczyciele $i$ dyrektorzy na tle międzynarodowym. Główne wyniki badania TALIS 2013, IBE, Warszawa 2014.

Konwencja o prawach osób niepetnosprawnych, Dz.U. RP 25 października 2012 r., pos. 1169, www.isap.sejm.gov.pl [access:15 lutego 2019].

Krause A., Wspótczesne paradygmaty pedagogiki specjalnej, OW Impuls, Kraków 2010.

Maciarz A., Integracja edukacyjna w świetle doświadczeń i oczekiwań dzieci niepetnosprawnych, w: Dziecko ze specjalnymi potrzebami edukacyjnymi w ekosystemie, red. W. Pilecka, A. Ozga, P. Kurtek, Wydawnictwo AŚ, Kielce 2005.

Maciarz A., Stosunki społeczne między uczniami petnosprawnymi i upośledzonymi umystowo, w: Wychowanie, ksztatcenie i przygotowanie do życia dzieci upośledzonych 
umystowo. Materiaty z konferencji naukowej (Kraków 16-17 maja 1984), red. J. Baran, J. Pilecki, Wydawnictwo WSP, Kraków 1985.

Mądrzycki T., Psychologiczne prawidtowości ksztattowania się postaw, WSiP, Warszawa 1997.

Mika S., Psychologia społeczna, PWN, Warszawa 1987.

Moran A., Can a competence or standards model facilitate an inclusive approach to teacher education? "International Journal of Inclusive Education”, 13(1), 45-61.

Plichta P., Wypalenie zawodowe i poczucie sensu życia pedagogów specjalnych, OW ATUT - Wrocławskie Wydawnictwo Oświatowe, Wrocław 2015.

Rozporządzenie Ministra Edukacji Narodowej z dnia 1 marca 2019 r. zmieniające rozporządzenie $\mathrm{w}$ sprawie szczegółowych kwalifikacji wymaganych od nauczycieli, Dz. U. z dnia 11 marca 2019 r., poz. 465.

Szkolnictwo wyższe w Polsce, Warszawa: Ministerstwo Nauki i Szkolnictwa Wyższego 2013

Szkoły wyższe i ich finanse w 2014 r., Warszawa: GUS 2015.

Szumski G., Wokót edukacji włączającej. Efekty kształcenia uczniów z niepetnosprawnościq intelektualna $w$ stopniu lekkim $w$ klasach specjalnych, integracyjnych $i$ ogólnodostępnych, współpraca A. Firkowska-Mankiewicz, Wydawnictwo APS, Warszawa 2010.

Śliwerski B., Edukacja (w) polityce. Polityka (w) edukacji. Inspiracje do badań polityki oświatowej, OW Impuls, Kraków 2015.

Warnock M., Special Educational Needs. Report of the Committee of Enquiry int Education of Handicapped Children and Young People, HMSO, London 1978.

Zarządzenie Nr 29 MEN z dn. 4.października 1993 r. w sprawie zasad organizowania opieki nad uczniami niepełnosprawnymi, ich kształcenia $w$ ogólnodostępnych i integracyjnych publicznych przedszkolach, szkołach i placówkach oraz organizacji kształcenia specjalnego, Dz.U. No. 19, poz. 167. 